HUNGARIAN AGRICULTURAL ENGINEERING

$\mathrm{N}^{\circ}$ 26/2014 5-10

Published online: http://hae-journals.org/

HU ISSN 0864-7410 (Print) / HU ISSN 2415-9751(Online)

DOI: 10.17676/HAE.2014.26.5
PERIODICAL OF THE COMITTEE OF AGRICULTURAL AND BIOSYSTEM ENGINEERING OF THE HUNGARIAN ACADEMY OF SCIENCES and SZENT ISTVÁN UNIVERSITY

Faculty of Mechanical Engineering

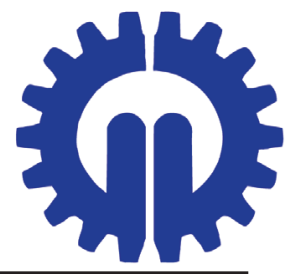

\title{
EXTERNALITY ANALYSIS OF SUSTAINABLE CATTLE BREEDING SYSTEMS
}

\author{
Author(s): \\ Cs. Fogarassy - M. Bakosné Böröcz
}

Affiliation:

Szent István University, Faculty of Economics and Social Sciences, Institute of Regional Economics and Rural Development.,1. Páter Károly street, Gödöllö, 2100, Hungary

Email address:

Fogarassy.Csaba@gtk.szie.hu, Borocz.Maria@gtk.szie.hu

\begin{abstract}
In Hungary, extensive beef production has a very long tradition. The importance of sustainability in agriculture is unquestionable, as it generates externalities as a by-product, which is to be managed. The problem of sustainability in agriculture could be handled long-term by extensive farming. According to [1] J.K. Bithas (2011), sustainable development requires a sufficiently long time period of consideration to cover the interests of generations even far in the future. Environmental impacts and the relevant environmental externalities inhibit the prospect of sustainability. Hence, externality is a key concept for sustainability. In our research, we highlighted the relevance of extensive cattle-breeding systems from a sustainability aspect.
\end{abstract}

\section{Keywords}

sustainable agriculture, extensive farming systems, benchmarking, externality

\section{Introduction}

The export of Hungarian livestock and beef was significant until the 80 's. However, the number of livestock is continuously decreasing nowadays, including the number of beef cattle as well. The reasons for this decrease were international and domestic, economic and social changes. The BSE epidemic in the 90's, the funding system for the beef sector, the elevated competition and the level of saturation on the international market all had negative effects on the sector. Due to extensive production, and cattle raised on grasslands, beef of good quality can be produced, which may serve as a basis for health prevention in the future. This kind of technology meets the criteria of sustainability, since the animals are fed with natural food, their diet doesn't include tankage that would lead to diseases. If we're searching for the connection between sustainability and the externalities, we can think back on Van de Bergh[2], who describes this connection as follows; if we internalize all externalities, which are inconsistent with sustainability, will we realize sustainable development. Van de Bergh [2] states: „Without environmental externalities, the problem of unsustainability vanishes". According to Bithas [1] environmental impacts cause environmental externalities, so they have extensive physical dimensions time- and space-wise. The problem of sustainability is mainly related to environmental impacts that affect future generations and individuals in geographically distant locations. Van de Bergh [2] concludes that sustainability is compatible with a positive level of externalities, defined by the assimilation capacity of the environment, and the technological status.

\section{Materials and methods}

In our research, we used benchmarking to validate our hypotheses that extensive farming systems have less externalities compared to intensive systems. Benchmarking originates from Robert $\mathrm{C}$. Camp [3], facilitating the spread of the benchmarking method. According to Camp [3] benchmarking means the discovery and realization of the never-failing best practices. Evans [4] says that benchmarking is a leadership tool, and if we use it, we can find the best business practices leading to performances of the highest level. It provides information which lets us view what we currently lack, thus helping to achieve the goals we set for ourselves.

Management has taken the expression 'benchmark' from surveying and architecture: it refers to a column made of stone with which other points correlate. The original meaning of the word is simply 'level of height'. According to Pálfalvi [5], we may call also this a level-improvement, since it is about defining where the target firm is compared to the others on the market, and what we need to do to improve its status, and develop its adaptability. To identify and examine the externalities of cattle breeding systems, benchmarking is a good solution, since externalities in agricultural production can be evaluated with this method.

In our research, we've investigated the impacts of different technologies on Hungary's meat-cattle sector. The information sources we used for the benchmarking analysis were professional sources, professional publications and statistics. We've carried out our investigations by combining the elements of functionaland process-based benchmarking. During the benchmarking, several questions can be raised: what should the aim of the analysis be, what the company and the sector should be compared to, etc. The information sources of benchmarking can be professional associations, chambers, experts, colleagues, suppliers, clients, professional magazines, publications, databanks, relationships and product analyses. According to Pigou [6] "An externality occurs in economics when a decision causes costs or benefits to stakeholders other than the person 
making the decision. In other words, the decision-maker does not bear all of the costs or reap all of the benefits from his action. As a result, in a competitive market, too much or too little of the good is consumed from the point of view of society." We examined the intensive and extensive farming systems in light of externalities, searching for the most sustainable variant of cattle-breeding farming.

During our analyses, we defined traditional technologies as an intensive/semi-intensive technology, where animals are kept in closed buildings, and large amounts of supplementary fodder are consumed. Intensive farming isn't widely used in Hungary, because it includes grazing as well, albeit to a much lesser extent compared to extensive or ecological farming [7]. We considered extensive farming to be when the animals mainly graze. They get supplementary feed, but much less compared to conventional technology. In this case however, we can't achieve the same volume of daily weight increase. Regarding ecological farming, feeding is primarily based on grasslands, but supplementary fodder also has to come from ecological farms, which causes the costs to increase. Ecological breeding is used mostly for Hungarian grey stock, since it tolerates extreme weather conditions quite well. It doesn't have high demands, but its reproduction capacity is lower than that of others [8]

During the benchmarking analysis, we have defined three aspects, based on the different technologies which we examined. These were the following: ecological, economic and technological. Within those aspects, we have analyzed 10 indicators in each case [9]. We have selected 10 indicators, because we intended to have a balance between the different aspects, since they have the same significance. We specified the indicators, after which we selected a base indicator, and assigned a performance indicator to it. In both cases, we explained the actuality of the selection. As for the different technologies, different impacts have to be considered. Therefore, this method was suitable for ranking the different possible solutions. The basis for defining the aspects and carrying out the research was professional sources, and my own examinations.

In the next part, we will give an example through animal manure to explain how we defined the status-, and performance indicators.

\section{Status indicator}

Dealing with manure created (Technological aspect: 6)

Reason for selecting the indicator: The quantity and quality of manure, and possible ways of its usage vary for different technologies. Liquid manure causes a lot of environmental problems. In ecological breeding, mainly the Hungarian grey is used, due to its frugality, thus its manure doesn't need any special treatment. This is also true for extensive breeding, since the nutrition content of the manure is absorbed by the grassland.

In conventional technology, the created manure ( $45 \mathrm{~kg} / \mathrm{animal})$ has to be transported and treated if necessary, meaning extra costs for the farmers.

The amount of manure created by cattle is summarized in Chart 1:

Chart 1. Manure of cattle

Source: Nyiri, [10]

\begin{tabular}{|l|c|c|}
\hline Livestock & Fecal $(\mathrm{kg})$ & Urine $(\mathrm{kg})$ \\
\hline Cattle: & $20,0-30,0$ & $10,-15,0$ \\
\hline
\end{tabular}

\section{Performance indicator}

Creation and treatment of manure according to different technologies: different amounts of manure have to be calculated by the farmers depending on the technology applied. Liquid manure is very dangerous for the environment, so having to dispose of it is inevitable.

Method for performance qualification: The amount of manure which has to be treated per animal.

The scale of my assessment was between $(-2)$ and $(+2)$ :

$(-2)$ extremely unfavorable effect: over 30 liters/animal daily

$(-1)$ unfavorable effect: over 20 liters/animal daily

(0) no effect:

$(+1)$ favorable effect: average 15-20 liters/animal daily less than 15 liters/animal daily

$(+2)$ extremely favorable effect:less than 12 liters/animal daily

In this analysis, conventional technology got (-2), extensive and ecological ones got $(+1)$, since the amount of manure is not significant in the cases of the extensive and ecological systems.

Following the above mentioned logic, according to the environmental aspects we can demonstrate the reason for selecting the indicator in the next way. If we have environmental status indicator „Utilizing environmentally sensitive lands” we can use as a performance indicator „Changes in the size of lands involved". In this context we analyzed the size of the involved environmental sensitive lands and we can state, that we can expand the grazing animal keeping extensive systems in this type of lands. We gave (-1) for the intensive system, since in this kind of lands there are strict regulations which have to be taken to consider. We gave $(+2)$ for the extensive and ecological ones since extensive farming systems can use this kind of lands.

When we analyze the status indicator „Possibility to open towards new sales channels" in the case of economic aspects we chose performance indicator „Trends of the market demand". We gave $(+2)$ for the intensive system, since in this kind products could be made in lower price than the ecological products, therefore it is easyer to enter to the market for them. We gave (0) for the extensive and (-2) ecological systems, since the market demand for the ecological products depends significantly from the solvent request of the people, and the marketing instruments.

During benchmarking, the products, services, and processes can be compared to each other in a way that the reasons for differences in performance can also be seen, and they highlight the possibilities for improvement. We have prepared the analysis based on such considerations, to examine the shortcomings and possibilities of each technology [11]. As a first step, we defined the elements of the Logframe - matrix. It helps us to see the logical relationship between the activities, results and goals. The cells of the Logframe - matrix are built on each other both vertically and horizontally.

\section{Logframe- matrix}

The Logframe Matrix (LFA) is a chart that includes the aims, the methods and indicators of control, and their necessary conditions (Chart 2). 
Chart 2. Logframe matrix for evaluation Source: Bakosné [11]

\begin{tabular}{|l|l|l|l|l|}
\hline & \multicolumn{1}{|c|}{ Aims } & \multicolumn{1}{c|}{ Indicators } & \multicolumn{1}{c|}{ Control } & External conditions \\
\hline Output & $\begin{array}{l}\text { To discover } \\
\text { externalities related } \\
\text { to meat-cattle } \\
\text { production }\end{array}$ & $\begin{array}{l}\text { Environmental,econ } \\
\text { omic and } \\
\text { technological } \\
\text { features }\end{array}$ & $\begin{array}{l}\text { Summarizing the } \\
\text { positive and } \\
\text { negative external } \\
\text { effects }\end{array}$ & $\begin{array}{l}\text { Regulatory } \\
\text { environment, } \\
\text { market acceptability }\end{array}$ \\
\hline $\begin{array}{l}\text { Direct } \\
\text { impact }\end{array}$ & $\begin{array}{l}\text { Resource-efficient } \\
\text { farming methods, } \\
\text { ecological-extensive } \\
\text { cattle breeding, } \\
\text { taking environ- } \\
\text { mental economic } \\
\text { aspects into } \\
\text { consideration- } \\
\text { protection of water } \\
\text { base }\end{array}$ & $\begin{array}{l}\text { Volume of manual } \\
\text { labor and energy, } \\
\text { newcomers of the } \\
\text { extensification } \\
\text { program, improving } \\
\text { environmental } \\
\text { conditions }\end{array}$ & $\begin{array}{l}\text { Analyzing changes } \\
\text { in the environment, } \\
\text { examination of } \\
\text { market viability }\end{array}$ & $\begin{array}{l}\text { The higher costs } \\
\text { must be accepted by } \\
\text { the market, } \\
\text { cooperation of } \\
\text { consumers, } \\
\text { information }\end{array}$ \\
\hline $\begin{array}{l}\text { Indirect } \\
\text { impact }\end{array}$ & $\begin{array}{l}\text { Levying tax on the } \\
\text { sources of negative } \\
\text { externalities, } \\
\text { supporting the } \\
\text { sources of positive } \\
\text { externalities }\end{array}$ & $\begin{array}{l}\text { Defining the } \\
\text { volume of support, } \\
\text { controlling } \\
\text { innovation capacity, } \\
\text { examination of } \\
\text { supply and demand } \\
\text { reactions }\end{array}$ & $\begin{array}{l}\text { Examination of } \\
\text { support- and tax } \\
\text { system }\end{array}$ & $\begin{array}{l}\text { Recognizing } \\
\text { positive and } \\
\text { negative } \\
\text { externalities in the } \\
\text { right way }\end{array}$ \\
\hline
\end{tabular}

\section{Results and discussion}

The results can be evaluated with the help of the indicators, comparing them to the goals. We defined three types of indicators:
1. indicators of environmental aspects (Chart 3)

2. indicators of technological aspects (Chart 4)

3. indicators of economic aspects (Chart 5)

Chart 3. Indicators of environmental aspects Source: Bakosné [11]

\begin{tabular}{|c|c|c|c|}
\hline & Environmental aspects & & \\
\hline Code & Status indicators & Code & Performance indicators \\
\hline 1. & $\begin{array}{l}\text { Effects related to soil } \\
\text { contamination }\end{array}$ & 1. & $\begin{array}{l}\text { The change in the quantity of materials } \\
\text { contaminating the soil. }\end{array}$ \\
\hline 2. & $\begin{array}{l}\text { Spread of farming methods adapted } \\
\text { to landscape }\end{array}$ & 2. & $\begin{array}{l}\text { Changes in the sizes of extensive and } \\
\text { ecological agricultural lands. }\end{array}$ \\
\hline 3. & $\begin{array}{l}\text { Utilizing environmentally sensitive } \\
\text { lands }\end{array}$ & 3. & Changes in the size of lands involved. \\
\hline 4. & Using grasslands & 4. & Changes in the size of grasslands grazed. \\
\hline 5. & In situ effect on natural treasuries & 5. & Impact on the landscapes. \\
\hline 6. & Maintaining biodiversity & 6. & $\begin{array}{l}\text { The constitution of the land, activities } \\
\text { influencing other varieties. }\end{array}$ \\
\hline 7. & $\begin{array}{l}\text { The amount of waste, handling } \\
\text { waste produced }\end{array}$ & 7. & $\begin{array}{l}\text { The amount of waste produced by } \\
\text { different technologies, and how to handle } \\
\text { them. }\end{array}$ \\
\hline 8. & Handling produced manure & 8. & $\begin{array}{l}\text { Manure produced and handled by the } \\
\text { various technologies. }\end{array}$ \\
\hline 9. & $\begin{array}{l}\text { Necessity of renewable energy } \\
\text { sources }\end{array}$ & 9. & $\begin{array}{l}\text { Quantity of non-renewable energy sources } \\
\text { needed. }\end{array}$ \\
\hline 10. & $\begin{array}{l}\text { Effects related to water } \\
\text { contamination }\end{array}$ & 10. & $\begin{array}{l}\text { Changes in the amount of materials } \\
\text { contaminating the water. }\end{array}$ \\
\hline
\end{tabular}


We considered status indicators from an environmental aspect, for example the use of grasslands, utilization of environmentally sensitive lands, or manure management. We also considered status indicators from a technological aspect, for example water usage, natural resource usage, and asset demand (Chart 4).

Chart 4. Indicators of technological aspects Source: Bakosné [11]

\begin{tabular}{|c|c|c|c|}
\hline \multirow[b]{2}{*}{ Code } & \multicolumn{3}{|l|}{ Technological aspects } \\
\hline & Status indicators & Code & Performance indicators \\
\hline 1. & Energy-conserving technologies & 1. & $\begin{array}{l}\text { Spread of energy-conserving, green } \\
\text { technologies }\end{array}$ \\
\hline 2. & Efficiency of manpower & 2. & Changes in the efficiency of manpower \\
\hline 3. & Keeping the environmental limits & 3. & Changes of environmental standards \\
\hline 4. & Greenhouse gas emission & 4. & Quantity of greenhouse gases \\
\hline 5. & Water usage & 5. & Water used by different technologies \\
\hline 6. & $\begin{array}{l}\text { Liquid manure produced using } \\
\text { different technologies }\end{array}$ & 6. & Quantity of liquid manure \\
\hline 7. & $\mathrm{CO} 2$ economical technologies & 7. & $\mathrm{CO} 2$ emission reduction \\
\hline 8. & Usage of natural resources & 8. & Quantity of natural resources used \\
\hline 9. & Asset demand & 9. & Fixed and current assets need \\
\hline 10. & Range of varieties & 10. & Number of varieties which can be used \\
\hline
\end{tabular}

Chart 5. Indicators of economic aspects Source: Bakosné [11]

\begin{tabular}{|l|l|l|l|}
\hline & Economic aspects & Code & Performance indicators \\
\hline Code & Status indicators & 1. & Changes in the volume of support \\
\hline 1. & Economic subventions & 2. & Extent of transition to extensive farming \\
\hline 2. & $\begin{array}{l}\text { Environmentally conscious } \\
\text { production }\end{array}$ & 3. & Costs and their changes \\
\hline 3. & Animal health costs & 4. & Costs of putting the product on the market \\
\hline 4. & Costs of entering the market & 5. & Ability to meet the domestic demand \\
\hline 5. & Domestic consumer needs & 6. & $\begin{array}{l}\text { Ability to meet the special consumer } \\
\text { demand }\end{array}$ \\
\hline 6. & Meeting special consumer needs & Exp poing the product possibilities using a \\
\hline 7. & $\begin{array}{l}\text { Possible expansion of the product } \\
\text { range }\end{array}$ & 7. & $\begin{array}{l}\text { Exploiting } \\
\text { given technology }\end{array}$ \\
\hline 8. & $\begin{array}{l}\text { Possibility to open towards new sales } \\
\text { channels }\end{array}$ & 8. & Trends of the market demand \\
\hline 9. & Supplementary forage demand & 9. & Need for supplementary forage \\
\hline 10. & $\begin{array}{l}\text { Costs related to the maintenance of } \\
\text { buildings }\end{array}$ & 10. & Changes in building maintenance costs \\
\hline
\end{tabular}

We evaluated the results of the benchmarking analysis, by summing up the values of each aspect (the last row of the table). While doing the assessment, we calculated the average of the two extreme values. We considered the value closest to this average to be the optimum.

Based on the evaluation of environmental aspects (Chart 6), we can say that the most positive externalities are accumulated by extensive breeding. Its average value is 6,33 . That means that's the case where most positive externalities are created. According to this, the extensive technology generates the highest amount of positive externalities. On the basis of environmental aspects, conventional technology accumulates the highest number of negative externalities. The extensive group is the closest one to the average value. Conventional technology has negative impacts on in-situ goods and biodiversity. It uses more non-renewable energy resources than the other two technologies. In addition, conventional technology uses a lot of water as well. Extensive and ecological farming are quite close to each other from an environmental point of view. The environmental burden is low in both cases. The transition towards extensive breeding is 
encouraged by subsidies because of such environmental effects. Extensive and ecological breeding can be carried out even in environmentally sensitive areas. The amount of liquid manure produced in extensive and ecological breeding is much lower, when compared to conventional practice. There isn't even water produced, therefore it doesn't pollute the soil.

Chart 6. Chart of the evaluation of environmental aspects Source: self-made

\begin{tabular}{|l|c|c|c|}
\hline Code & Conventional & Extensive & Ecological \\
\hline 1 & 0 & +1 & +2 \\
\hline 2 & -1 & +1 & +2 \\
\hline 3 & -1 & +2 & +2 \\
\hline 4 & +1 & +2 & +2 \\
\hline 5 & -2 & +1 & +2 \\
\hline 6 & -2 & +1 & +2 \\
\hline 7 & -1 & +1 & +1 \\
\hline 8 & -2 & +1 & +2 \\
\hline 9 & -2 & +1 & +2 \\
\hline 10 & -1 & 0 & +2 \\
\hline SUM & -11 & +11 & +19 \\
\hline
\end{tabular}

Chart 7. Chart of evaluation of technological aspects Source: self-made

\begin{tabular}{|c|c|c|c|}
\hline Code & Conventional & Extensive & Ecological \\
\hline 1 & 0 & +1 & +1 \\
\hline 2 & +2 & 0 & 0 \\
\hline 3 & +1 & +1 & +2 \\
\hline 4 & -1 & 0 & +1 \\
\hline 5 & -1 & 0 & 0 \\
\hline 6 & -2 & +1 & +1 \\
\hline 7 & -1 & +1 & +2 \\
\hline 8 & -1 & 0 & +1 \\
\hline 9 & +1 & -1 & -1 \\
\hline 10 & +1 & 0 & -1 \\
\hline SUM & -1 & +3 & +6 \\
\hline
\end{tabular}

On the basis of technological aspects (Chart 7), extensive farming seemed to be the best regarding energy efficiency and liquid manure creation. Conventional technology accumulated the most externalities regarding this as well. As for the remaining ones, energy use, greenhouse gas emission and the use of natural resources depend on technology applied. And as for the variety, not all varieties are suitable for using in ecological farming. There is no significant difference between ecological and extensive farming regarding the technological aspects. The average value is 2,66 .

Chart 8. Chart of evaluation of economic aspects Source: self-made

\begin{tabular}{|l|c|r|r|}
\hline Code & Conventional & Extensive & Ecological \\
\hline 1 & +1 & +0 & +1 \\
\hline 2 & +2 & +0 & +1 \\
\hline 3 & -2 & -1 & 0 \\
\hline 4 & +2 & +1 & -2 \\
\hline 5 & +2 & +1 & 0 \\
\hline 6 & +2 & 0 & -2 \\
\hline 7 & +2 & 0 & -2 \\
\hline 8 & +2 & 0 & -2 \\
\hline 9 & +1 & 0 & -2 \\
\hline 10 & +2 & +1 & +1 \\
\hline SUM & +14 & +2 & -5 \\
\hline
\end{tabular}

On the basis of economic aspects (Chart 8), we can say that ecological farming accumulates the most negative externalities. The average value is at 3,66. Economic aspects include meeting the standards and consumer demands, exploiting market possibilities, and the costs of entering the market. Based on such aspects, ecological technology accumulated the most negative externalities, since it has the highest administrative requirements and the highest costs required as well. The other two breeding methods didn't have notable advantages in this respect, because the costs and the regulatory elements won't allow too much space for the farmers to decide. From an ecological aspect, conventional technology accumulates the most positive externalities, since production can be more cost-efficient under intensive conditions. On the basis of average value, extensive breeding is the economically optimal solution, since it can help meet consumer demands. The need for supplementary forage is low, and the system of subsidies encourages this type of farming as well. Ecological breeding lags behind extensive, since the farmers need to meet several conditions for it; furthermore, it requires more administration, and not all varieties are suitable for this type of breeding. Quality procedure results in higher administrative loads, regulations on forage are compulsory for the farmers, thus it is more costly compared to the other two.

Summarizing all the aspects, we can state that extensive breeding creates the most positive externalities. Conventional breeding accumulates the most negative externalities.

Chart 9. Summarizing evaluation tables Source: self-made

\begin{tabular}{|l|c|c|c|c|}
\hline Type of production & $\begin{array}{c}\text { Conventional } \\
\text { production }\end{array}$ & $\begin{array}{c}\text { Extensive } \\
\text { production }\end{array}$ & $\begin{array}{c}\text { Ecological } \\
\text { production }\end{array}$ & $\begin{array}{c}\text { Market } \\
\text { equilibrium } \\
\text { value }\end{array}$ \\
\cline { 1 - 2 } $\begin{array}{l}\text { Type of evaluation } \\
\text { aspect }\end{array}$ & -11 & +11 & +19 & 6.333 \\
\hline Environmental aspect & -1 & +3 & +6 & 2.666 \\
\hline Technological aspect & +14 & +2 & -5 & 3.666 \\
\hline Ecologic aspect & +3 & +16 & +20 & 13 \\
\hline $\begin{array}{l}\text { Summary of external } \\
\text { effects } \\
\text { (arithmetic average) }\end{array}$ & & & & \\
\hline
\end{tabular}

After summarizing the data of the previous charts (Chart 9), we arrived at the conclusion that extensive farming creates the highest amount of externalities. Based on the research, conventional breeding causes higher environmental burden, and has more negative externalities than the other two. The problem is that exaggerated externality content cannot be validated in the form of money on the market, since consumers intend to pay for it only to a certain extent. Accumulating too 
many positive or negative externalities is therefore not desirable.

\section{Conclusions}

While comparing the results of the benchmarking analysis, we have come to the conclusion that extensive technology is the best from both environmental and economic aspects for the domestic meat-cattle sector. There is grassland in both sufficient quantity and quality in Hungary to allow extensive cattle fattening to expand further. This type of breeding is also preferred by the European Union, thus encouraging the activity with premiums related to extensive meat-cattle breeding. The agriculture's environmental footprint seems to have grown in past decades, as agriculture has become more and more industrialized. The cons of industrial agriculture are the damages caused by it, such as degradation of natural resources and biodiversity. After assessing the environmental aspects, the conclusion is that extensive breeding was the one that accumulated the fewest externalities, creating the fewest positive and negative impacts. However, positive externalities are fewer in the case of extensive technology compared to ecological, but compared to intensive farming systems, we can say it's more sustainable long-term. From the economic aspects, we can state that the most financial negative externalities occur under ecological conditions, since the fixed costs are higher due to the strict regulations. The distance from market equilibrium shows how sustainable the analyzed systems are. This distance is lowest for the extensive production system, which shows its sustainability, according to the three different key resources.

From an environmental aspect, the conventional, while from an economic aspect, the ecological farming aggregates the highest amount of externalities. The less adequate the equilibrium on the market is, the more externalities will be present. From the viewpoint of technological aspects, the system which is the best platform for innovation is the extensive production, with the least amount of externalities (value of 3). The distance from market equilibrium (Chart 10) clearly shows us the results of the multiaspect benchmarking. According to the analysis, extensive farming can be called the most sustainable system operation, while conventional production generates the highest amounts of externalities (value of 10) in the resource system.

Chart 10. Distance from the market equilibrium Source: self-made

\begin{tabular}{|l|c|c|c|}
\hline $\begin{array}{l}\text { Type of } \\
\text { production }\end{array}$ & $\begin{array}{c}\text { Conventional } \\
\text { production }\end{array}$ & $\begin{array}{c}\text { Extensive } \\
\text { production }\end{array}$ & $\begin{array}{c}\text { Ecological } \\
\text { production }\end{array}$ \\
\hline $\begin{array}{l}\text { Distance from } \\
\text { market } \\
\text { equilibrium }\end{array}$ & 10 & 3 & 7 \\
\hline
\end{tabular}

The role of cost-efficient raw material production in the fattening industry is expected to become more prominent in the future, and the technology chosen will have a greater significance. Due to the extensive technology, costs may be saved, since it does not require costly assets, and the forage costs may also decrease due to grazing. In addition, when adhering to extensive and ecological farming, meeting the animal welfare and animal health standards does not cause difficulty for the farmers. By reasons of economic aspect, the framework of the agricultural production system in both the EU and Hungary has to be changed, due to the externality aggregations which can either be positive or negative. Without internalization of these external effects, we cannot balance our food production system in a sustainable way.

\section{References}

[1] Bithas, K. Sustainability and externalities: Is the internalization of externalities a sufficient condition for sustainability? Ecological Economics 70, 2011.p 1703-1706

[2] Jeroen, van den Bergh Externality or sustainability economics? Ecological Economics 69, 2010. p. 2047-2052.

[3] Camp, R. C. : Üzleti folyamat benchmarking (Camp, R. C. 1995. Business Process Benchmarking. American Society for Quality.). Budapest, 1998, Müszaki Könyvkiadó. pp. 298.-309 (language: Hungarian)

[4] Evans, S. - Dale, B.G.: „Benchmarking the engineer availability process: A case study", Benchmarking: An International Journal, ( 1), (1997) pp. 7 - 17

[5] Pálfalvi, J. A benchmarking módszerről I., A Tudás 365 napja+1, [IX]. 2002.

http://www.valtozovilag.hu/t365/tux0928.htm

[6] Pigou, A. C. The Economics of Welfare, Macmillian, Part II., London, 1920.

http://files.libertyfund.org/files/1410/Pigou_0316.pdf

[7] Marsalek, S. Környezeti állapot, mezögazdaság, fenntartható fejlödés (Environment, agriculture and sustainable development). Gazdálkodás [50] 2006. p. 12-27

[8] Farkas, F. M. - Fogarassy, C. - Szucs, I. Allowance for external effects in efficiency calculations. In: Edited by Szucs. I. -Fekete. F. M. - Efficiency in the agriculture (Theory in practice) Agroinform Publisher, Budapest, 2008. p. 114-122

[9] Fogarassy, Cs. Externalities in the agriculture - commodity and non-commodity outputs in the local food providing systems. Development Prospect of Rural Areas Lagging behind in the CEE Region, Visegrad Founders' Conference, 24-27 May, 2011. Gödöllö.

[10] Nyiri, L. Földműveléstan (Soil cultivation). Mezőgazda Kiadó, Budapest, 1993. p. 45-60

[11] Bakosné, B. M.: Economic analysis and environmental assessment of cattle breeding, In: Economics and sustainable agriculture, Gödöllö, 2011, pp. 152-173 